\title{
Women and Welfare: The Politics of Coping with New Social Risks in Chile and Uruguay
}

Jennifer Pribble

University of Richmond, jpribble@richmond.edu

Follow this and additional works at: http://scholarship.richmond.edu/polisci-faculty-publications Part of the Models and Methods Commons, and the Politics and Social Change Commons

\section{Recommended Citation}

Pribble, Jennifer. "Women and Welfare: The Politics of Coping with New Social Risks in Chile and Uruguay." Latin American Research Review 41, no. 2 (June 2006): 84-111. doi:10.1353/lar.2006.0028.

This Article is brought to you for free and open access by the Political Science at UR Scholarship Repository. It has been accepted for inclusion in Political Science Faculty Publications by an authorized administrator of UR Scholarship Repository. For more information, please contact scholarshiprepository@richmond.edu. 


\title{
WOMEN AND WELFARE \\ The Politics of Coping with New Social Risks in Chile and Uruguay ${ }^{1}$
}

\author{
Jennifer Pribble \\ University of North Carolina, Chapel Hill
}

Received: 8/19/2004; Revise and Resubmit 10/31/2004:

Revised received: 2/22/05; Final Acceptance 6/20/2005

\begin{abstract}
Women make up a disproportionate share of the world's poor, and Latin America is no exception to this trend. Nevertheless, very few studies of social policy in the region have investigated why the gendered character of welfare provision varies across countries. This article addresses that question through a comparative historical analysis of Chile and Uruguay and concludes that variation in the gendered nature of each state's social policy regime resulted from a two-step process. In the first stage, female labor force participation, the mobilizing capacity of women, and policy legacies differentiated the two countries, placing Chile on a less equitable trajectory than Uruguay. These differences were then magnified during each state's experience under authoritarian rule.
\end{abstract}

Most scholars of economics, political science, and sociology recognize that women make up a disproportionate share of the world's poor. Latin America has not been immune to this trend, and a recent study found that "nearly half of women older than fifteen years of age do not have access to an independent income, compared to twenty percent of men in the same age group" (ECLAC 2004, 139 [translation by author]). Despite the clear gendered differences in Latin American poverty, analyses of the region's welfare states ${ }^{2}$ have focused primarily on explaining

1. This paper has benefited enormously from the insightful comments of professors and colleagues. In particular, I would like to thank Evelyne Huber and Inés Valdez, who read and commented on multiple versions of the text. Merike Blofield, Mireya Davila, Agustina Giraudy, Jonathan Hartlyn, Mala Htun, Juan Pablo Luna, Lars Schoultz, John Stephens, and four anonymous reviewers also offered extremely helpful feedback on earlier versions of the paper. Any shortcomings that remain are my own. I would also like to acknowledge the support of the University of North Carolina at Chapel Hill's Institute for Latin American Studies and the Mellon Foundation, which funded two months of research in Uruguay during 2003.

2. I have chosen to use this term despite clear differences between the scope of Latin American social policy regimes and those of most advanced industrialized economies.

Latin American Research Review, Vol. 41, No. 2, June 2006

(C) 2006 by the University of Texas Press, P.O. Box 7819, Austin, TX 78713-7819 
differences in overall social spending levels. ${ }^{3}$ This focus has neglected an important point of variation between Latin American welfare regimes: the gendered character of social policy. This paper aims to fill this hole in the literature. Through a comparative analysis of Chile and Uruguay, the following pages explore how and why Latin American countries vary in their abilities to formulate policy that responds to the unique social risks that women face.

The design of social policy regimes has a profound impact on women's material well-being as well as on the formation of societal definitions of a woman's role as a citizen, worker, and caregiver. While some welfare regimes reproduce traditional gender roles, other systems provide women with opportunities to reduce their dependency on both the market and the family. Additionally, some welfare regimes are able to address the specific social risks women face more effectively than others, producing lower levels of female poverty and male-female wage dispersion and higher levels of female labor-force participation. Finally, welfare systems can influence gender equity through the quality and coverage of education, because improving women's access to schooling provides them with better and higher-paying jobs. ${ }^{4}$

Ensuring equal social protection for women is important for many reasons. First, there is the normative expectation that democratic regimes will grant equal rights to all citizens regardless of sex, race, age, etc. Secondly, reducing women's exposure to risk is important for reversing recent growth in poverty and inequality in Latin America. The Chilean government estimates that between 1990 and 1996, 19.5 percent of households escaped poverty because of female entry into the labor force (ECLAC, 2000a, 51).

The comparison of Chile and Uruguay is useful because similarities between the two countries, (level of economic development, history with democracy, and stability of the party system) allow me to control for a number of rival hypotheses. More importantly, the case selection provides special insight into the issue of gender and welfare because Chile and Uruguay have similar levels of social spending, yet markedly different policy outcomes. ${ }^{5}$ While the Chilean welfare state is an example

3. Examples include Brown and Hunter (1999); Dion (2001); Huber (1996); Kaufman and Segura (2001).

4. According to the United Nations Development Program (2004), the combined primary, secondary, and tertiary school enrollment rates for men and women in Uruguay is 81 and 90 percent respectively. In Chile, those same figures are 80 and 79 percent respectively.

5. The two countries spent approximately 7 percent of GDP on health and education in 1999. Chile and Uruguay's spending patterns do differ with regard to social security and welfare expenditure (with Chile spending approximately 8 percent of GDP while Uruguay spends 19 percent) (Huber et al. 2006). Still, both countries are among the top four spenders in the region and have similarly long traditions of welfare policy. 
of a gender-biased regime, Uruguay's social policies exhibit greater gender neutrality. ${ }^{6}$ The findings of the paper suggest that gendered variation between Chile and Uruguay's welfare states results from a two-step process. In the first stage, female labor force participation, the mobilizing capacity of women, and policy legacies differentiated the two countries, placing Chile on a less equitable trajectory than Uruguay. These differences were then magnified during each state's experience under authoritarian rule.

\section{NEW RISKS AND NEW WELFARE: WHAT ARE THE ISSUES?}

The traditional welfare state seeks to protect workers against risks encountered in the market, namely the loss of income due to unemployment, sickness, disability, and old age. In recent decades, however, new risks have emerged alongside traditional issues. In Latin America, these new risks include the shrinking of the formal sector and subsequent growth of the unregulated informal market and dramatic changes in the family structure. Women have been particularly affected by the emergence of these new risks because of their dual dependency on the family and the market. Indeed, changes in family structure, namely a rising divorce rate and an increase in single-parent households, typically run by women, have increased women's exposure to risk.

In conjunction with this shift away from the traditional family structure, the composition of the Chilean and Uruguayan labor-force has experienced a dramatic transformation in recent years. Women have increasingly moved out of unpaid domestic work and into the formal and informal labor markets in both countries, although to a lesser degree in Chile. At the same time, unemployment has increased and international competition has resulted in a reduction of low-skill jobs.

As a result, many workers have been forced into the informal sector, which is defined as "all income-earning activities that are not regulated by the state" (Portes and Schauffler 1993, 6). ECLAC (2002) estimates that as many as 50 percent of Latin American workers in urban centers function in the informal sector (195-196). Because of the low-skill nature of much informal work and the flexibility that it offers, women are more likely to engage in it than men. Contreras (2003) finds that 44.8 percent of working-aged women in Chile functioned in the informal sector in 1998, while only 32.9 percent of men worked informally (6064). A 2004 ECLAC study suggests that this same gendered division of

6. This does not imply that Uruguay has a perfect record on gendered rights. Indeed, women's organizations have criticized the government for being slow to implement portions of the United Nations' Convention on the Elimination of all Forms of Discrimination Against Women (Cladem n.d.). 
informal sector employment exists in Uruguay (162). In response to the emergence of these new social risks, citizens have, in some cases, urged politicians to respond with policy innovations. Chile and Uruguay have varied in their ability to address the risks faced by women. I now turn to assessing this variation.

\section{A GENDERED ANALYSIS OF SOCIAL POLICY: BREADWINNER VERSUS CITIZEN WELFARE}

The dependent variable of this study is the gendered nature of each country's welfare regime. To measure this, I modify Sainsbury's (1996) framework of two "ideal type" welfare regimes: the male breadwinner and the citizen model. The male breadwinner ideal type is characterized by unequal provision of benefits and entitlements that are grounded in an individual's position in the labor market and/or family. The citizen welfare state, on the other hand, provides universal protection regardless of an individual's sex and status in the market.

For the purpose of this article, Sainsbury's framework is more useful than those developed by Orloff (1993), O'Conner, Orloff, and Shaver (1999), or Fraser (1996) for several reasons. First, Sainsbury's categorization permits an analysis of individual policy sectors. This is not the case for Orloff's framework, which contains dimensions that assess the overall character of the (full) welfare state. Similarly, Orloff, O'Conner, and Shaver are explicit in focusing their analysis on each country's total policy regime (12). It is clear, therefore, that the focus of Orloff and Orloff, O'Conner, and Shaver's work is broader than the scope of this article. Likewise, Fraser's framework, which focuses on seven principles of gendered equality, is also intended for analyses of the entire welfare state. Sainsbury's framework, by contrast, provides dimensions that can be used to measure individual policy sectors. Furthermore, the specification of clear and identifiable elements in Sainsbury's framework allows for a systematic comparison. ${ }^{7}$

Sainsbury's framework was developed for the analysis of advanced industrialized welfare states, and must be modified for research on Latin American social policy. Unlike in advanced industrialized democracies, the dichotomous distinction between breadwinner and citizen welfare regimes is not useful for analyses of Latin America because no state in the region provides citizen-style welfare. Rather, Latin American social policy tends to vary with regard to the strength of the breadwinner model. For this reason, it is more useful to employ Sainsbury's dimensions but evaluate policies with regard to the relative "strength of bread-

7. For the purpose of this argument, I have omitted five of Sainsbury's dimensions: familial ideology, the tax system, the unit of contribution, employment and wage policies, and caring work (paid or unpaid). 
winner" instead of classifying programs as "breadwinner" or "citizen." I use four of Sainsbury's nine analytic categories. The first dimension of the framework is welfare entitlement, which refers to what social rights are available to citizens. In some social policy regimes the rights of women and men differ with regard to the level and type of benefit, while in other cases no distinction is made between the sexes. The second dimension of Sainsbury's framework is the basis of entitlement, or the means by which individuals gain access to welfare transfers and services. I also analyze the recipient of the benefit, which allows for an assessment of women's access to welfare programs vis-à-vis their male counterparts. The final dimension of Sainsbury's framework is the unit of benefit, which describes who (what risk group) the welfare program targets.

To determine the strength of the breadwinner model in Chile and Uruguay, I analyze three policy sectors: family allowances, childcare, and maternity leave. I have chosen to limit my focus to three areas for two reasons. First, the space of a paper will not permit an analysis of the full welfare state. Furthermore, the three policy areas are similar in that each program seeks to address the dual demands that women face in acting as caregivers and workers. In this way, the policy domains provide a good assessment of each state's ability to reduce women's dependence on the market and the family.

In the following section I discuss each policy area, evaluating the program along the lines of Sainsbury's four dimensions. This discussion is summarized in table 1.

\section{Family Allowances}

Chile and Uruguay both offer family allowances to impoverished families. In Chile, men and women have access to family allowances, but the entitlement requirements are not equal across the sexes. Chilean men and women qualify for the allowance if they have dependent children under the age of eighteen (or twenty-four if in school). The entitlement changes, however, with regard to the spouse's status. Men qualify for a family allowance if they have dependent wives, but women only receive an allowance if their husbands are disabled (U.S. Social Security Administration 1999, 77, 378). Put differently, working women in Chile do not receive the same level of family allowance benefits as working men. The Uruguayan family allowance system does not make this distinction, but rather pays a set amount for each dependent regardless of the head of household's sex.

The family allowance systems in Chile and Uruguay also differ with regard to the basis of entitlement. In Chile, allowances are available to "employed persons and pensioners with one or more children or other eligible dependents" (U.S. Social Security Administration 1999, 77), while 
Table 1 Summary of Policy Classification

\begin{tabular}{|c|c|c|}
\hline & Chile & Uruguay \\
\hline \multicolumn{3}{|l|}{ Family Allowances } \\
\hline Entitlement & Unequal across sexes & Equal across sexes \\
\hline Basis of Entitlement & $\begin{array}{l}\text { Extremely limited } \\
\text { (must be formally } \\
\text { employed and with } \\
\text { contract). }\end{array}$ & $\begin{array}{l}\text { More inclusive (larger } \\
\text { number of work } \\
\text { categories and no } \\
\text { contract limitation). }\end{array}$ \\
\hline Recipient of Benefits & Head of household & Head of household \\
\hline Unit of Benefit & Family & Family \\
\hline $\begin{array}{l}\text { Overall Breadwinner } \\
\text { Maternity Leave }\end{array}$ & Strong breadwinner & Weak breadwinner \\
\hline Entitlement & Unequal across sexes & Unequal across sexes \\
\hline Basis of Entitlement & $\begin{array}{l}\text { Limited (same limits } \\
\text { as family allowances) }\end{array}$ & $\begin{array}{l}\text { More inclusive (more } \\
\text { job categories and } \\
\text { recently unemployed } \\
\text { women are covered). }\end{array}$ \\
\hline Recipient of Benefits & Mother & Mother \\
\hline Unit of Benefit & Household & Household \\
\hline Overall Breadwinner & Strong breadwinner & Breadwinner \\
\hline \multicolumn{3}{|l|}{ Childcare } \\
\hline Entitlement & Unequal across sexes & Equal across sexes \\
\hline Basis of Entitlement & $\begin{array}{l}\text { Very limited (must be } \\
\text { formal sector worker } \\
\text { with a contract) }\end{array}$ & $\begin{array}{l}\text { More inclusive (no job } \\
\text { is required; targeting is } \\
\text { based on family } \\
\text { income) preschool } \\
\text { program is universal } \\
\text { and therefore } \\
\text { completely inclusive }\end{array}$ \\
\hline Recipient of Benefits & Working mother & $\begin{array}{l}\text { Any household } \\
\text { member who } \\
\text { demonstrates need. }\end{array}$ \\
\hline Unit of Benefit & Family & Family \\
\hline Overall Breadwinner & Breadwinner & Weak breadwinner \\
\hline Overall Regime Type & Strong breadwinner & Weak breadwinner \\
\hline
\end{tabular}


in Uruguay the benefit is extended to a wider range of individuals: "employed persons, domestic workers, persons in receipt of unemployment benefits, newspaper and small rural products vendors, and pensioners" (U.S. Social Security Administration 1999, 377). This diversity of entitlement base provides Uruguayan women with better access to family allowances, since many domestic workers and small vendors are female. Additionally, in 2004 Uruguay passed a law extending coverage of family allowances to all households with incomes of less than three times the minimum wage, including those headed by individuals working in the informal sector (Uruguay, Presidencia de la República 2004), where it is estimated that women are overrepresented. Incorporating these categories of workers into the entitlement base boosts women's access to the benefit in Uruguay.

Another factor that negatively affects Chilean women's ability to secure access to family allowances (and all labor-based welfare transfers) is the county's two-tiered employment system, which grants social welfare benefits to some workers, while denying them to others. Chilean workers who are subject to contract have access to all labor-market-based welfare benefits, while individuals who are paid on a boleta, or a receipt, do not enjoy the same privileges. It is important to note that boleta workers are formal sector employees, but their status is less than that of contracted workers.

Access to fully contracted work is diminishing in Chile, while the boleta system has become more prevalent. Between 1996 and 2000, the percentage of all salaried workers with contracts decreased from 80 to 77 percent for men and from 78 to 72 percent for women (De la Luz Trautmann 2002). Furthermore, high-income earners are much more likely to have a contract than low-income individuals. In 2000, 86.5 percent of females working in the formal sector with earnings in the top income quintile were contracted laborers, while only 39.7 percent of women in the bottom income quintile had contracts. Additionally, the gap between the number of men and women who have contracts is largest among the poor. In 2000, the difference in contract coverage between male and female workers in the top income quintile was 1.5 percentage points, while in the bottom income quintile, the difference in coverage was 18.6 percentage points (De la Luz Trautmann 2002). It is clear, therefore, that a large proportion of low-income women are employed through the boleta system rather than by contract. This means that very few poor women have access to welfare benefits even when they work in the formal labor force. ${ }^{8}$

8. The Chilean state provides a limited number of means-tested family allowances to households that do not qualify for the employment-based system. Nonetheless, this benefit is separate from the primary family allowance program and thus I do not include it in the analysis. 
The recipient of the family allowance benefit in both the Chilean and Uruguayan case is the head of household (U.S. Social Security Administration 1999, 77, 378). Additionally, the unit of benefit in both cases is the family rather than the individual (ibid.). On these two dimensions, therefore, the two countries exhibit similar levels of breadwinner strength. In summary, both Chile and Uruguay offer family allowances to needy families, but the programs differ in important ways. In Chile, family allowances are unequal across the sexes, and the basis of entitlement is limited because of the segmented nature of the labor market. In Uruguay, by contrast, men and women are provided with equal benefits and the system has been expanded to offer protection to a broader portion of the population.

\section{Childcare}

The Chilean government created a system of subsidized childcare in 1994. The recipients of this benefit are working mothers who qualify through the country's socioeconomic targeting scheme. To qualify, the household must score no more than a minimum number of points on the targeting survey and the mother must show an employment contract and proof of working hours (Clert and Wodon 2001, 60). In this way, the basis of entitlement to Chile's childcare program is restricted along two dimensions: an individual's labor market position and household income. The system, therefore, excludes four groups of potential beneficiaries: women whose household income exceeds the minimal target amount, women working in the informal sector, women looking for work, and women who are employed, but not by contract. As I have previously demonstrated, low-income women who work in the formal sector are unlikely to be employed by contract.

Uruguay also provides a form of state-subsidized childcare to a small group of low-income families. Beginning in the 1930s, but expanding dramatically during the 1980s and 1990s, the Uruguayan state developed neighborhood-based Infant and Family Attention Centers (CAIF). The aim of CAIF is to "improve the well-being, level of development, and social insertion of families in high socioeconomic risk groups through nutrition programs, health attention, education, and family assistance" (Midaglia 2000,63 [translation by author]). Childcare was not a focus of the CAIF program originally, but with time, the centers have begun to function as a form of daycare. CAIFs operate during the workday, and according to the staff, many women use the service as a form of childcare (Midaglia 2000).

While successful, the CAIF program is limited in scope. ${ }^{9}$ The most common complaint about the centers is that many families do not have 
access to the service. Indeed, one-third of CAIF centers report having a waiting list that represents 60 percent of its current coverage (Midaglia $2000,67)$. The government uses a targeting scheme to determine which families have access to CAIFs. The targeting method relies on family income and the age of children in the household. Families with children under four and pregnant and nursing women receive priority (Midaglia $2000,68)$. The effectiveness of this targeting method is buttressed by the fact that centers only operate in low-income neighborhoods and provide services to individuals living in the community. Women are not required to show proof of employment to access the service, and therefore females in the informal sector and individuals looking for work are able to use the childcare services. The CAIF targeting scheme is efficient at providing services to Uruguay's poorest families. An estimated 80.7 percent of CAIF services are used by the lowest 20 percent of income earners. The remaining 19.3 percent of users are from the second-poorest income quintile (Murrugarra 2000, 23).

In addition to the CAIF system, Uruguayan parents benefit from a de facto form of daycare that the country's near-universal preschool program provides. Uruguay's 1995 education reform instituted a system of universal public preschool for children between the ages of three and five. The preschool classes are held during the normal school/work day, and therefore, the program serves as an unofficial form of daycare for many parents. Coverage of the preschool program is extremely high. In 2001, the enrollment of three year olds was 39 percent, while attendance by four year olds was 72 percent. Enrollment figures for five-year-old children are the most impressive, with approximately 91 percent attending preschool (Anep-Codicen 2002). ${ }^{10}$

In summary, entitlement to childcare services in Uruguay is equal across the sexes, as both men and women can obtain access to CAIF programs and enroll children in preschool, thus securing a de facto form of daycare. The universal nature of preschool education and the progressive targeting system used for the CAIF program provide a more inclusive basis of entitlement to childcare than that which exists in Chile's childcare system. The unit of benefit in both Chile and Uruguay is the family, but the recipient of benefits varies across the two cases with women receiving the subsidy in Chile, while both men and women receive it in Uruguay. For all of these reasons, I have scored Chile's childcare system as a breadwinner model and Uruguay's program as a weak breadwinner type.

10. Chile also provides public preschool, but the coverage is limited with only about 32 percent of children between three months and five years of age attending preschool (data from author interview with Silvia Belmar, Santiago, Chile, August 12, 2005). 


\section{Maternity Leave}

Both Chile and Uruguay offer paid maternity leave to women working in the formal sector. In Chile, women with work contracts have the right to six weeks leave before and twelve weeks after the birth of the child. In Uruguay, the leave is six weeks before and six weeks after the birth of the child. Both countries provide women with 100 percent of their salary during the time of leave (U.S. Social Security Administration 1999; Servicio Nacional de la Mujer n.d.). Additionally, Chile grants women a one-hour feeding break each day until the child is two years old, while Uruguay provides the break only until the child is six months old (Abramo 2002,3). At first glance, the Chilean system seems to be more generous than the Uruguayan system, offering greater flexibility for women to enter and exit the labor force, but many female workers are denied access to the benefit because of the two-tiered employment system.

Entitlement to the maternity leave benefit is differentiated between spouses in both the Chilean and Uruguayan case. Neither country provides for the possibility of men taking paternity leave, as is the case in some advanced-industrialized welfare states. Both countries, therefore, should be considered breadwinner models with regard to entitlement to maternity leave. The basis of the entitlement in both cases is also strongly breadwinner in design. Neither country offers financial support to pregnant women who have never been attached to the labor market. Uruguay, however, does provide a broader entitlement base. Rights to the maternity allowance are extended to self-employed individuals as well as to women receiving unemployment benefits (U.S. Social Security Administration 1999, 376). This is important because it provides protection to women who have recently lost jobs, a right that does not exist in the Chilean system. Furthermore, it should again be noted that in Chile the entitlement base is greatly reduced by the fact that only contract workers are eligible for maternity leave. The unit of benefit and the recipient of the benefit is the household in both Chile and Uruguay and therefore both countries should be considered breadwinner on those dimensions.

This analysis of Chile's and Uruguay's family allowance, childcare, and maternity leave policies suggests that there are important differences between the two countries with regard to the gendered nature of welfare programs. Indeed, while Chile's system is representative of a very strong breadwinner model, Uruguayan policy demonstrates weaker breadwinner tendencies. Table 1 provides a summary of the crossnational differences on each of the four dimensions considered in this analysis. One aspect that emerges from the table is that the majority of variation between Chile and Uruguay is rooted in differences in program entitlements and in the basis of entitlement. While Chilean policy tends to be unequal across the sexes and very limited in coverage 
because of the large number of informal or boleta workers, Uruguay offers more equal benefits to men and women and has worked to expand the basis of entitlement so as to create more universalistic programs.

\section{AN EXPLANATION OF GENDERED DIFFERENCES}

Differences in the gender friendliness of Chile's and Uruguay's social policy regimes are best explained in terms of a two-step process. Pre-1973 gendered variation between the two countries' social policy regimes resulted from differences in the evolution of each state's labor market, the mobilizing capacity of women, and characteristics of the party system. Specifically, the evolution of each country's labor market affected women's mobilizing capacity, which in turn influenced the ideological and gendered distribution of power within the country. Women's ability to shift the gendered distribution of power was also conditioned by characteristics of the party system. As societal attitudes about gender shifted in response to women's growing power, constraints on gendered and nongendered social policy formation loosened. The policies that emerged from this process (both gendered and nongendered), fed a feedback mechanism that reshaped aspects of the labor market and the context in which women's mobilization was carried out, creating a "virtuous cycle" in Uruguay and a disadvantageous cycle in Chile.

Although this virtuous cycle explains initial gendered differences between Chile and Uruguay, a second step is required to understand contemporary variation between the two states' welfare regimes. Indeed, although gendered differences existed between the two countries in the early to mid-twentieth century, the gap widened during Chile's and Uruguay's military regimes. The Chilean government's adoption of orthodox neoliberal economic reforms, coupled with the junta's ability to further entrench ideological and institutional constraints on genderfriendly policy making, had a profound impact on the gendered character of Chile's post-authoritarian welfare state. Uruguay's dictatorship, by contrast, was less orthodox with regard to economic policy and was unable to institutionalize protections for conservative factions of the country's traditional political parties. ${ }^{11}$

\section{Structural Labor Market Conditions}

The starting point for conceptualizing variation in Chile's and Uruguay's gendered social policy outcomes is the difference in women's labor market participation. As displayed in table 2, Uruguayan women 
Table 2 Female Labor Force Participation, Select Years (Percent)

\begin{tabular}{lllll}
\hline & \multicolumn{2}{c}{ Chile } & \multicolumn{2}{c}{ Uruguay } \\
& Level & Change & Level & Change \\
\hline 1960 & 19.7 & & 24.2 & \\
1970 & 18.1 & -1.6 & 26.2 & 2 \\
1980 & 20.4 & 2.3 & 32.4 & 6.2 \\
1990 & 25.4 & 5 & 40 & 7.6 \\
2000 & 31.4 & 6 & 44.1 & 4.1 \\
\multicolumn{2}{l}{ Source: ECLAC (various years) Statistical Yearbook. } \\
\hline
\end{tabular}

entered the formal work force at a much faster pace than Chilean women. ${ }^{12}$ Although female involvement in the labor market has grown throughout the world during the past seventy-five years, the trend was likely intensified in Uruguay because of the high demand for labor. Historically, the country's small population and highly urbanized context created a strong demand for workers, thus providing Uruguayan women with unique opportunities denied to their Chilean counterparts.

As Uruguayan women gained increased access to the labor market, they obtained a new level of political relevance. One way that female labor market participation increased women's political clout was through unionization. Unions facilitate mass mobilization by providing individuals with organizational infrastructure and a direct channel through which to access the political/policy-making process. In this way, women's involvement in Uruguayan trade unions propelled female demands into the political arena. Ensignia and Yáñez (1999) note differences in the level of female unionization in Chile and Uruguay, arguing that the greatest barriers to women's participation in these groups are found in Chile (20). In Uruguay, by contrast, the authors note that women have made several important achievements such as the creation of the Tripartite Commission for Equal Opportunity and a special Women's Job Training Division in the Labor Ministry (62). ${ }^{13}$

The fact that Uruguayan women entered the labor market and began to organize themselves earlier than Chilean women marked an important difference between the two countries. Similarly, as Uruguayan women began to earn an independent income, they increased their economic power and mobility. In Chile, by contrast, low levels of female

12. Female labor force participation is the percentage of all women between the ages of fifteen and sixty-five who are active in the formal labor market. I could find no comparable data that predates 1960 .

13. I was unable to find historical figures on women's unionization in Chile and Uruguay. However, evidence from Alma Espino and Paola Azar (2004) and Chile's Servicio Nacional de la Mujer (online database, n.d.), suggests that women's involvement in Uruguayan trade unions in the 1990s was five percentage points higher than in Chile. 
labor force participation hindered the organizational and economic resources that women possessed to issue policy demands.

\section{Women's Mobilization, Political Parties, and Policy Legacies}

Different levels of female labor market participation in Chile and Uruguay, in turn, shaped the gendered distribution of power in each country. Changes in the power distribution were not automatic, but resulted from the mobilization of women's interests. Uruguayan women in the second half of the twentieth century built on a strong tradition of mobilization. Indeed, by 1916, Uruguayan women's groups had demonstrated their growing economic and political power. Female workers founded the National Women's Council, which organized meetings and protests to demand voting rights. Although Uruguayan women were not granted suffrage until 1932, the Communist Party began efforts to incorporate women into the political organization in the 1920s (Garrido 2000, 149). The Communist Party was not alone in its desire to attract women to the party base, and in 1931 the Colorado Party created the Batllista Feminist Committee, which provided women with unique access to political resources (Garrido 2000, 149). Although Chile also had an active women's suffrage movement, the suffrage groups' ties to political parties were not as strong, which limited their long-term mobilizing capacity. Evidence of the differential political clout enjoyed by women in both countries is seen in the fact that Chilean women won the right to vote in national elections in 1949, seventeen years after their Uruguayan counterparts.

Variation in the level of women's incorporation into political parties in Chile and Uruguay is in part explained by the level of female mobilization in each state, but is also conditioned by the character of both countries' party systems. Indeed, the Uruguayan party system, which at that time was composed of two catchall parties with factions that spanned the full ideological spectrum, provided unique incentives for the early incorporation of women because the elite sectors of the country were politically divided between the two parties. The existence of a divided and electorally-oriented elite that monopolized access to state-resources to furnish incentives to their constituencies, induced parties to seek the incorporation of subordinated groups, such as women, as a way to widen their electoral bases and institutionalize their support (Luna 2005). In Chile, the same situation did not occur, and pressures to extend voting rights emerged only after outsider parties entered the system (Luna 2005). More importantly for this paper, however, the evolution of the Chilean party system involved the emergence in the 1930s of a strong Christian Democratic Party (The Partido Demócrata Cristiano [PDC]). The party is important because its strength imposed ideological constraints on the formation of gender-friendly policy in Chile. 
Differences between Christian Democratic welfare policies and those of secular left parties have been widely researched in the literature on European welfare states. These differences exist in both gendered and nongendered terms. ${ }^{14}$ Esping-Andersen (1999) argues that Christian Democratic welfare regimes in Europe tend to be "familialistic" because the regimes are "influenced by Catholic social teachings and the principle of subsidiarity: limiting public interference to situations where primary social networks_-read family_fail" (51). This resistance on the part of Christian Democratic parties to allow for state involvement in the private sphere leads to noninterventionist family and social policy (Van Kersbergen 1995, 187-191). Such noninterventionist policy has negative consequences for gendered outcomes because without altering the traditional family structure, it is difficult to reduce women's dependency. Chile's experience under Christian Democratic rule (during both the preand post-authoritarian periods) corroborates findings from research on European welfare states. In Uruguay, by contrast, the role of the PDC has been much less notable. Uruguay's PDC was formed in 1962 following a political division within the Catholic-based party, Unión Cívica (Mainwaring and Scully 2003, 49). The party went on to help found the leftist coalition of parties, the Frente Amplio (FA), but never became a strong electoral force.

While Chile and Uruguay's party systems did generate divergent opportunity structures for feminist organizations, it must be noted that women's mobilization (or lack thereof) had an independent effect on gendered policy outcomes as well. Lavrin (1995) finds support for this fact, noting that women activists and public health officials were the driving force behind legislative achievements that increased protection for female workers in the early twentieth century (87). In the case of Uruguay, women's growing political power resulted in Jose Batlle y Ordóñez's 1906 proposal of a pre- and post-natal leave law, which was expanded by subsequent Colorado legislative proposals in 1908, 1911, and 1913. Similar legislation did not emerge in Chile until 1919, and even then, the measures represented a more conservative effort to protect women. Lavrin (1995) notes that in the early to mid-twentieth century, "Chile lagged behind Argentina and Uruguay in protective [labor] legislation [for women and children]" (77).

Uruguay's "virtuous cycle" of increased political power was not matched in Chile. As demonstrated in table two, female labor force participation in Chile has been consistently lower than in Uruguay, thus hampering women's access to a structured space (the workplace) within which to organize interests and develop power resources. The slow movement of women into the labor force complicated the efforts by 
Chilean feminist groups to shift the gendered balance of power within society. Evidence of this fact is seen in the passage of conservative legislation aimed at blocking women's employment in the mid-1930s. Indeed, at the same time that Uruguayan women were securing greater job safety, Chilean president Arturo Alessandri supported a bill to restrict women's employment in government and municipal offices and to limit minimum wage rights to male workers (Lavrin 1995, 94).

This particular historical incident serves as a good example of the importance of female actors and women's mobilization in securing more equitable social policy. In Chile, where women had limited access to work, and thus exerted weaker mobilizing capacity, women were unable to resist the gender-regressive policy of President Alessandri. At the same time in Uruguay, reports of weak enforcement of a law aimed at protecting female workers prompted one of the country's first female deputies to mobilize legislative support for the creation of a new department in the National Labor Office that was dedicated to supervising women and youth working conditions (Lavrin 1995, 84). In short, women's mobilizing capacity mattered in both positive and negative terms for the fate of gendered social policy formation in both Chile and Uruguay.

In addition to the slow entry of women into the labor force, several characteristics of Chile's women's movement, namely the existence of sharp class divisions and a hesitation to enter the policy-making sphere, have also undermined groups' capacity to mobilize support for genderfriendly policies and alter societal preferences about gender roles. In her work on the Chilean women's movement, Baldez (2002) argues that historically, a good deal of Chilean women's mobilization has unfolded outside the traditional (state) policy making sphere (10-15). Indeed, despite an abundance of organizations, Chilean women's groups largely engaged in activities outside the realm of state politics and, therefore, did not enjoy institutionalized access to the policy-making domain.

\section{The Legacy of Authoritarianism: Neoliberal Social Policy and Ideological Constraints}

Differences in female labor force participation and women's mobilizing capacity worked in conjunction with aspects of each country's party system to generate gendered differences in Chile and Uruguay's welfare states in the early to mid-twentieth century. This variation widened during each country's respective military rule because the authoritarian regimes that took hold in Chile and Uruguay in 1973 were different in style and scope and therefore generated divergent regime legacies. Specifically, while the Uruguayan dictatorship was unable to dismantle the country's welfare state, Chile's military junta engaged in a dramatic process of economic liberalization, privatizing and eliminating several welfare programs (Castiglioni 2005). 
Upon consolidating its power, the Chilean military junta enacted a strict process of liberalization and cost containment, dismantling many of the country's social welfare programs. The result was dramatic growth in poverty and income inequality. The Gini index grew from 47.4 in 1971 to 58.5 in 1990. Similarly, the share of households living in poverty grew from 17 percent in 1970 to 39 percent in 1987 (Huber et al. 2006). Although Gen. Augusto Pinochet's liberalizing project was not explicitly gendered, the reforms had gendered consequences. This is because the welfare state that remained following Chile's dictatorship was a residual means-tested regime, which used targeting as the primary mechanism for addressing social risk (Clert and Wodon 2001). The high levels of poverty and inequality, the introduction of the two-tiered labor market, ${ }^{15}$ and use of targeted social spending, undermined the sense of shared fate that Chilean women possessed prior to the dictatorship. The loss of this sense of shared fate destroyed the cross-class character of Chile's pro-welfare coalition, hindering the ability of many sectors of society, including the women's movement, to mobilize and present unified pro-welfare demands. In this way, divisions that existed in the women's movement prior to 1973 grew more dramatic in the wake of the dictatorship. Baldez (2002) notes that one source of conflict within the women's movement was that popular sector organizers perceived that gender issues were being favored over problems of class and redistribution (183-188).

Indeed, feminist mobilization has been weak since the return to democracy. Ríos Tobar (2004) argues that inter-movement divisions and institutional characteristics of the center-left Concertación coalition governments have debilitated the women's movement and undermined the political force of feminism (119). One source of division and dissent within the women's movement is Chile's continuing high level of income inequality (Blofield 2006). The military regime also influenced women's mobilization by consolidating the power of technocrats within the Chilean political process (Montecinos 1998). Technocratic politics, which have continued to thrive in Chile since the transition, disadvantage women's groups by limiting their access to the policy-making domain while privileging the access of business and economic groups (Montecinos 1998, 105).

Unlike Chile, the maintenance of relatively universal social policy in Uruguay has generated low levels of income inequality. ${ }^{16}$ Greater equality has strengthened the cross-class nature of Uruguay's pro-welfare coalition. In addition to strengthening the pro-welfare coalition, low

15. See previous discussion of the boleta system for an explanation of this policy.

16. Uruguay's Gini index has been steady around 40 since the 1980s. This is much lower than Chile, which had an average Gini of 58.5 in the 1990s. Chile's Gini has remained above 55 since the democratic transition (Huber et al. 2006). 
levels of income inequality have provided a stable base for women's mobilization. From its very inception, the Uruguayan welfare state has benefited all classes of women. Ehrick (2001) notes that both middleand lower-class women benefited from Batllismo and were therefore invested in its protection and expansion (138-139). In short, the multiclass nature of the Uruguayan welfare state provided middle- and lower-class women with a sense of linked fate, which has in turn facilitated a united mobilization of gendered demands. ${ }^{17}$

The virtuous cycle that accounted for initial differences between Chile and Uruguay has continued in the wake of the authoritarian regime. Following the transition back to democracy, Uruguayan women have continued to create organizational spaces within political parties and labor unions to advance their interests. As a result, an equal opportunity employment law was approved in 1989 and further expanded upon in 1999. These laws granted women additional rights and facilitated greater entry into the labor market, which further intensified women's mobilization and allowed for additional alterations in the gendered distribution of power. This process has moved forward largely because of women's activity in civil society groups and political parties. Although moves to incorporate women into parties began with the Colorados in the 1930s, recent attempts to secure the female vote have been made by the center-left Frente Amplio (FA) and Nuevo Espacio (NE) coalitions (Laurnaga 2001, 2).

Uruguayan women have also been elected to congressional offices and appointed to ministerial posts. In March 2000, female deputies in Uruguay's Congress banded together to create a formal women's bancada, or legislative coalition. The group's primary aim is to promote legislation that expands women's rights (Garrido 2000, 151). Thus far, the coalition of female legislators has pushed a bill through the House of Deputies that would legalize additional forms of abortion..$^{18}$ The bancada also introduced debate over the adoption of a legislative quota system for women. Although these policy initiatives have subsequently been paralyzed, the mere existence of a formal alliance of progressive female politicians provides Uruguayan women with a channel to pursue demands for more equal social rights. While the simple presence of women in government does not ensure increased representation of women's rights and feminist issues (Htun and Jones 2002, 52), in the case of Uruguay the presence of the bancada has, at the very least, opened a space

17. It is interesting to note that Uruguay's feminist movement emerged simultaneous to the expansion of the country's welfare state. This differs from Chile and may explain differences in the nature of each country's women's movement (Ehrick 2001).

18. Some forms of abortion, such as therapeutic abortion, are already legal in Uruguay. The same is not true in Chile, where all forms of abortion are illegal. 
for the discussion of issues that had previously gone unaddressed. This is likely because the formation of the bancada goes beyond a descriptive (quota-based) representation of females in Congress; rather, the group was formed with the stated aim of promoting women's interests. In Chile, by contrast, female deputies have not been able to form a similar coalition, despite their presence in both the congress and in ministerial positions.

Very different ideological constraints also accounted for historical differences in the gendered character of Chile and Uruguay's welfare regimes. While the Uruguayan party system divided elite interests and encouraged the early enfranchisement of women, the Chilean system did not. Further, the relative strength of the right and of the PDC also influenced Chile's early gendered social policy outcomes. These constraints on gender-friendly policy were further strengthened during and immediately following Pinochet's government. In Uruguay, by contrast, the traditional Church and the right have been weaker and were not strengthened by the military dictatorship, which if anything undermined the legitimacy of conservative actors.

The constraints that resulted from the strength of Chile's rightist parties have been present throughout the country's history, but the military regime strengthened these forces by adding institutional protections to the 1980 constitution, which safeguarded the representation of elite conservative interests through the creation of the binomial electoral system and the appointment of "senators for life."19 In Chile's binomial electoral system, citizens elect two representatives per district. The first seat is awarded to the candidate who wins the largest number of votes. In order to secure the second seat, however, the winning coalition must garner twice as many votes as the opposing party alliance. In this way, the system favors minority parties or coalitions that might not otherwise win a seat. In practice this has offered protection to the parties of the right since the transition to democracy. The constitutional provision for lifetime senators also ensured special representation for conservative groups, because the rules for assigning these positions favored former allies of the military regime. The presence of institutionalized protection for Chile's rightist parties and organizations is significant because it has helped the conservative alliance block the creation and reform of several gender-friendly social policy proposals (Blofield 2006).

Chile's military regime also influenced the strength and the ability of the traditional Catholic Church to impose ideological constraints on social policy making. Since the return to democracy, the Church has maintained both direct and indirect involvement in the political arena. The

19. In 2005 the Chilean constitution was reformed to eliminate the senator for life provision. 
Church's direct power is largely derived from its role in the country's democratic transition. Proof of this fact is provided by Htun's (2003) study, which demonstrates that cooperation between Church actors and anti-Pinochet groups at the time of the transition secured an important role for the Church in postauthoritarian politics (107).

The Church also exerts power in Chilean policy making through the PDC. Since Chile's return to democracy, the Concertación has controlled the government. The Concertación is a coalition of center-left parties: the PDC, the Party for Democracy (PPD), the Socialist Party (PS), and the smaller Radical Social Democratic Party (PRSD). Prior to the 2000 parliamentary elections, the PDC was the dominant force in the coalition and the single largest party in Chile (Huneeus 2003, 146). While the coalition between the PDC and other secular-left parties creates a situation of unlikely bedfellows, the parties have preserved the partnership because of incentives presented by the electoral system. As Carey (1997) notes, the importance of political coalitions in contemporary Chilean politics has created a situation in which "coalition leaders negotiate candidate nominations jointly and can impose discipline across all members of the coalition" (93). The strength of the PDC within the Concertación and this discipline across party lines is important for understanding gendered differences in Chilean social policy, because the traditional character of the party makes it particularly resistant to policies that acknowledge changes in family structure and in the role of women. Noting that legislation related to women's rights in the 1990-2002 period was most successful when it did not reshape conventional views of women and the family, Blofield and Haas (2005) argue that "the Christian Democratic party has publicly expressed its recognition of women's inequality, but at the same time, the party is hesitant to introduce legislation on issues that will bring it into conflict with the Church" (14).

Since the return to democracy in Uruguay, by contrast, the PDC has remained weak. Although the party was one of the original founders of the FA (Martínez Barahona 2001, 525), by 1989 some members of Uruguay's PDC abandoned the FA to join the slightly more moderate NE (Mainwaring and Scully 2003, 49). Although Uruguay's Christian Democratic Party is now represented in both the FA and NE coalitions, it is insignificant in electoral terms.

The secular nature of the FA has granted the coalition leeway in pursuing policies that recognize the changing nature of the family and women's roles in society. Indeed, the party group appears more willing to create policy that intervenes in the private sphere of the home. Since the FA only recently won the presidency, it is difficult to test this proposition, but the party platform reveals the FA's willingness to break with traditional conceptions of women and the family. For example, the platform names female-headed households as its primary "social risk" 
focus group (Encuentro Progresista 1999, 21). Additionally, the FA created a special section of policies for women, which focused primarily on boosting female labor market participation and increasing women's financial autonomy (Encuentro Progresista 1999, 40).

In summary, differences in women's entry into the labor market in Chile and Uruguay shaped the gendered power distribution in both countries by providing women with divergent political and organizational resources. The character of each state's party system also provided opportunities for (in the case of Uruguay) and constrained (in the case of Chile) women's ability to mobilize demands through political organizations. These differences in women's mobilizing capacity, in turn, affected the character of social policy. As policies took hold, a virtuous cycle was created in Uruguay: women entered the labor force and began to be mobilized through unions and parties. This mobilization helped achieve more gender-friendly policies, which further increased women's labor force participation. Such a cycle did not play out in Chile, where females joined the work force at a slower pace and tended to mobilize interests outside of the political sphere.

These initial gendered differences between Chile and Uruguay further widened following both countries' experiences under military rule. In the case of Chile, the Pinochet government's strict adoption of neoliberal economic and social policies dramatically altered the country's social structure, concentrating high levels of wealth and political power among a small, elite group. As inequality grew, divisions emerged within the women's movement. These divisions hindered (and continue to affect) the ability of women's groups to mobilize unified demands for more equitable social policy (Blofield 2006). In addition to growth in poverty and inequality, other aspects of the Pinochet government's neoliberal reform process, namely the creation of a two-tiered labor market and the privatization of health and social security services, undermined the coherence of gendered social policy demands. This is because women were divided into contract workers and boleta workers, and private healthcare users and public healthcare users. These divisions altered the character of women's demands and greatly reduced the perception of shared fate.

Additionally, by providing special protections to the right, Chile's military regime strengthened ideological constraints that limit gender-friendly social policy development. The military-era constitution strengthened the parties of the right by instituting an electoral system that favors minority parties and by providing for senators for life. Finally, the close cooperation between pro-democracy forces and Church actors during the Chilean transition also ensured an important political role for the traditional Catholic Church in posttransition politics (Htun 2003). In Uruguay, the military regime was 
unable to dismantle the country's welfare state, the political right was discredited, and the Church continues to be a relatively unimportant actor in national politics.

\section{COMPETING THEORIES}

One beneficial aspect of selecting Chile and Uruguay as cases for analysis is that it allows me to control for a number of potential explanatory variables, thereby eliminating several rival hypotheses. Indeed, the fact that Chile and Uruguay exhibit similar levels of economic development suggests that the gendered character of a country's welfare state is not solely determined by national income. Similarly, the fact that both countries have a long experience with democracy and exhibit stable party systems underscores the fact that gendered differences can and do exist in settings of highly institutionalized and democratic politics.

Several other competing theories cannot be ruled out without a closer examination. One rival explanation that seems plausible at first glance is political culture. Indeed, the observed variation in Chile's and Uruguay's gendered social policy regimes might simply be the result of Chile's conservative culture and Uruguay's more liberal character. I maintain, however, that the countries' political cultures can be unpacked into more clearly defined variables for this analysis. Specifically, Chile's conservative cultural attitudes about women's roles must be understood in the context of strong and institutionalized rightist parties and the Catholic Church. For this reason, I analyze the right and the Church, thereby attempting to operationalize the country's cultural conservativism. In this way, I seek to uncover how culture is produced and reproduced in Chile and Uruguay. By approaching the issue of culture from this angle, I avoid problems that arise in attempting to define and measure a concept as tenuous as culture.

Other critics might argue that the theory presented here is more complex than it needs to be. They may contend that historical differences in female labor force participation, women's mobilization, and the character of the party system are not important for contemporary gendered variation between Chile and Uruguay. Rather, they may argue that the legacy of each country's military regime can sufficiently explain crossnational gendered differences in social policy. This assertion, however, does not hold up when confronted with historical data. Indeed, important gendered differences already existed between Chile and Uruguay prior to each state's authoritarian period. Thus, while the Pinochet regime did exacerbate differences between the two countries, it does not sufficiently explain the variation between the cases. 


\section{CONCLUSION}

In this article I seek to explain gendered differences in Chile's and Uruguay's welfare regimes through an analysis of three policy sectors: family allowances, maternity leave, and childcare. The policy evaluation reveals that Chile's social policy regime is a very strong breadwinner model, while Uruguay's policies are a weaker version of the breadwinner type. I find that the gendered differences in Chile's and Uruguay's welfare policies result from a two-part process that involves the interaction of female labor force participation, women's mobilization, party system characteristics, policy legacies, and the impact of each country's military regime. The theory presented here (one of "virtuous" and "disadvantageous" cycles) does not imply that change is impossible in Chile and Uruguay, but rather that the possibilities for progressive gendered social policy reform are heavily conditioned by historical legacies. It is interesting to note, however, the theory specified in this paper suggests that two recent developments in Chile and Uruguay could have important gendered consequences in the medium to long term. First, recent increases in the levels of poverty and in the size of Uruguay's informal sector may influence (in a negative manner) women's mobilization and the cross-class nature of gendered social policy formation in that country. In Chile, by contrast, the election of a female president (Michelle Bachelet) may provide an opening within the center-left alliance for the mobilization of women's demands. Both of these developments can be understood and integrated into the explanation presented in this paper.

The findings presented in this article have several interesting implications. The study is one of the first research projects to probe the question of how and why Latin American welfare states vary with regard to the protection of women's social rights. Indeed, previous research on Latin American social policy has focused on the overall character of social protection, thereby neglecting the existence of important gendered differences in the region's welfare policy. In this respect, the analysis of Chile provides special insight. Since the return to democracy, Chile's Concertación governments have invested significant political and economic resources in expanding social welfare programs. The result has been a tremendous reduction in overall poverty, from 38.6 percent in 1990 to 20.6 percent in 2000 (ECLAC 2002, 211, 223). This rapid decrease was not matched, however, for female-headed households living in poverty. Indeed, while overall poverty decreased 18 percentage points between 1990 and 2000, the share of female-headed households living in poverty decreased only 9.8 percent. It is interesting, then, that although an analysis of Chile's general welfare regime might conclude that public policy has been extremely effective at addressing poverty, 
improvements in welfare have not been equally distributed across society. This difference suggests a new arena for future research on Latin American political economy.

In addition to gendered differences in the provision of social rights, this paper highlights significant variation in the overall organization of Latin American welfare states. The fact that cross-national differences in social policy exist in Latin America is significant because it suggests that the conclusions of some analysts, that Latin America has entered a uniform "race to the bottom" with respect to social policy, may be premature. Rather, the evidence presented here suggests that Latin American welfare regimes vary in significant and systematic ways. Furthermore, the fact that sizable differences exist between Chile's and Uruguay's welfare policies suggests that there is room within the open-market economic model for different degrees of social protection. Indeed, despite Uruguay's high level of economic openness, the country offers greater protection to women than Chile, also an extremely open country. This lends support to the argument advanced by Huber and Solt (2004) that assessments of neoliberal economic reforms in the region should analyze the character and speed of the reform process rather than considering the simple dichotomy of "reformers" and "nonreformers." To better understand the consequences of neoliberal reforms for women's wellbeing, future studies of gender and social policy should consider whether variation in the speed and timing of reforms influences the quality of women's social rights and the possibility for subsequent progressive gendered policy reform.

This paper also has implications for studies of women's mobilization and feminist movements. One of the current debates in the field of women's politics has to do with the issue of whether or not strong ties between feminist groups and state organizations can serve the interests of women. Put differently, the debate is about autonomy versus partnership. ${ }^{20}$ The findings presented here suggest that cooperation between women's groups and traditional political and state actors can have beneficial outcomes for women. Specifically, in Uruguay the fact that women mobilized within unions and parties helped feminist groups channel demands into the policy-making arena. In Chile, by contrast, the distance between feminist organizations and state actors appears to have undermined the ability of many groups to have their voices heard in the policy-making process.

Clearly, then, this is a topic that deserves further research. The differences highlighted in this analysis of three policy sectors suggest that future studies should consider whether similar gendered variation 
exists in health, education, and pension policy and if such differences exist in other countries as well. ${ }^{21}$ There is also a need for scholars to construct analytic frameworks that correspond to the unique aspects of Latin American social policy regimes. Indeed, while the use of Sainsbury's (1996) framework is functional, a great deal more may be learned by including dimensions that are particularly relevant in Latin American social policy making, such as the presence of a large informal sector and low levels of industrial employment. Hite and Viterna's (2005) analysis of gender and class in Latin America provides an excellent base for the creation of such a framework. The authors track recent changes in the Latin American class structure, paying special attention to gendered stratification. Their findings about the impact of women's increased labor force participation on the strength of the working class shed new light on the dynamics of change in Latin America's social policy regimes.

The formation of this and other such frameworks that consider questions of gender and welfare in Latin America would benefit all scholars of political economy, not just those who research the region. Indeed, as Madrid (2003) points out in his study of pension privatization in Latin America, research on comparative welfare states has evolved quickly during the past twenty years, but it has been based predominantly on studies of advanced industrial democracies. Expanding this research to include Latin American cases would provide a new and important field for testing extant theories. 


\section{8

\section{REFERENCES}

Abramo, Laís

2002 "Costos laborales de hombres y mujeres en países de América Latina: Mitos y realidad." International Labour Organisation. www.oit.org.pe/gpe/ documentos/doc_costos_comut_abramo_18mar03.pdf

ANEP-CODICEN

2002 "Serie Estadística Educativa: Gerencia General de Planeamiento y Gestión Educativa." http://www.anep.edu.uy/gerenciagrl/ger_gral/estad2.pdf

Arenas de, Alberto, and Verónica Montecinos.

1999 "The Privatization of Social Security and Women's Welfare: Gender Effects of the Chilean Reform." Latin American Research Review 34 (3): 7-37.

Baldez, Lisa

2002 Why Women Protest. New York: Cambridge University Press.

Blofield, Merike H.

2006 Moral Politics in Catholic Countries: Policy Reform on Abortion and Divorce in Chile, Argentina and Spain. New York: Routledge.

Blofield, Merike H., and Liesl Haas

2005 "Defining a Democracy: Reforming the Laws on Women's Rights in Chile, 19902002." Latin American Politics and Society 47 (3): 35-68.

Brown, David S., and Wendy Hunter

1999 "Democracy and Social Spending in Latin America, 1980-92." American Political Science Review 93 (4): 779-790.

Carey, John

1997 “Chile: Latin American Proportionality or Majoritarianism?" In The International IDEA Handbook of Electoral System Design, edited by Andrew Reynolds and Ben Reilly, 93-94. Stockholm: International Institute for Democracy and Electoral Assistance.

Castiglioni, Rossana

2005 The Politics of Social Policy Change in Chile and Uruguay: Retrenchment Versus Maintenance, 1973-1998. New York: Routledge Press.

CLADEM (Comité de América Latina y el Caribe Para la Defensa de los Derechos de la Mujer)

n.d. "Monitoring Compliance with the United Nations Convention on The Elimination of all forms of Discrimination Against Women." http://www.cladem.org/ espanol/regionales/monitoreo\%5Fconvenios/cedaw_uruguay.asp

Clert, Carine, and Quentin Wodon

2001 "The Targeting of Government Programs in Chile." In Measurement and Meaning Combining Quantitative and Qualitative Methods for the Analysis of Poverty and Social Exclusion in Latin America, World Bank Technical Paper No. 518, edited by Estanislao Gacitúa Marió and Quentin Wodon, 43-68. Washington D.C.: World Bank.

Contreras, Victoria

2003 "Medición del Sector Informal." In Políticas de Empleo en Chile y America Latina: Seminario en Honor de Víctor E. Tokman, edited by the Oficina Internacional del Trabajo. Santiago: International Labor Organization.

De la Luz Trautmann, María

2002 "Comercio y género: Las políticas de liberalización y sus impactos en Chile." Working Paper: International Gender and Trade Network. www.generoy comercio.org/docs/publicaciones/ investigaciones/sintesis.pdf

Dion, Michelle

2001 "Trade Liberalization, Political Regime Type, Participation and Social Spending in Latin America, 1980-1994." Unpublished paper presented at: Centro de Investigación y Docencias Económicas (CIDE). Mexico City, Mexico.

ECLAC (Economic Commission on Latin America and the Caribbean)

Various Years Statistical Yearbook for Latin American and Caribbean. Santiago, Chile: United Nations Publications.

2000 Las mujeres chilenas en los noventa: Hablan las cifras. Santiago, Chile: United Nations Publications.

2002 Social Panorama of Latin America. Santiago, Chile: United Nations Publications. 
2004 Social Panorama of Latin America. Santiago, Chile: United Nations Publications. Ehrick, Christine

2001 "Affectionate Mothers and the Colossa Machine: Feminism, Social Assistance, and the State in Uruguay, 1910-1932." The Americas 58 (1): 121-139.

Encuentro Progresista

1999 El otro programa. Montevideo: Encuentro Progresista-Frente Amplio.

Ensignia, Jaime, and Sonia Yáñez

1999 Inserción laboral femenina: Sindicalismo, género, y flexibilización en el Mercosur y Chile. Santiago: Centro de Estudios de la Mujer.

Esping-Andersen, Gøsta

1999 Social Foundations of Postindustrial Economies. New York: Oxford University Press.

Espino, Alma, and Paola Azar

2005 "Changes in Economic Policies in Uruguay from a Gender Perspective (19302000)." UNRISD Mimeo.

Fraser, Nancy

1996 "Gender Equity and the Welfare State: A Postindustrial Thought Experiment." In Democracy and Difference, edited by Seyla Benhabib, 218-241. Princeton: Princeton University Press.

Garrido, Lucy

2000 "Uruguay." In Guía de las Mujeres 2000, edited by Carina Gobbi, 149-152. Montevideo: Instituto del Tercer Mundo.

Hite, Amy Bellone, and Jocelyn S. Viterna.

2005 "Gendering Class in Latin America: How Women Effect and Experience Change in the Class Structure." Latin American Research Review 40 (2): 50-82.

Htun, Mala

2003 Sex and the State. New York: Cambridge University Press.

Htun, Mala, and Mark Jones

2002 "Engendering the Right to Participate in Decisionmaking: Electoral Quotas and Women's Leadership in Latin America." In Gender and the Politics of Rights and Democracy in Latin America, edited by Nikki Craske and Maxine Molyneux, 3256. London: Palgrave Press.

Huber, Evelyne

1996 "Options for Social Policy in Latin America: Neoliberal versus Social Democratic Models." In Welfare States in Transition: National Adaptations in Global Economies, edited by Gøsta Esping-Andersen, 141-191. London: Sage Publications.

Huber, Evelyne, Tom Mustillo, Jennifer Pribble, and John Stephens

2006 "Social Policy in Latin America and the Caribbean Data Set," Department of Political Science, University of North Carolina, Chapel Hill.

Huber, Evelyne, Charles Ragin, and John Stephens

1993 "Social Democracy, Christian Democracy, Constitutional Structure, and the Welfare State." The American Journal of Sociology 99 (3): 711-749.

Huber, Evelyne, and Fred Solt

2004 "Successes and Failures of Neoliberalism." Latin American Research Review 39 (3): 150-164.

Huber, Evelyne, and John Stephens

2001 Development and Crisis of the Welfare State. Chicago: University of Chicago Press.

Huneeus, Carlos

2003 "A Highly Institutionalized Political Party." In Christian Democracy in Latin America, edited by Scott Mainwaring and Timothy R. Scully, 121-161. Stanford: Stanford University Press.

Kaufman, Robert, and Alex Segura

2001 "Globalization, Domestic Politics, and Social Spending in Latin America." World Politics 53 (July): 553-587.

Laurnaga, Maria Elena

2001 Análisis de las campañas electorales: Uruguay. Montevideo: Mujeres del Sur Publications.

Lavrin, Asunción

1995 Women, Feminism, and Social Change in Argentina, Chile, and Uruguay, 1890-1940. Lincoln: University of Nebraska Press. 
Luna, Juan Pablo

2005 "Chile and Uruguay: The Evolution of Programmatic and Non-Programmatic Party-Voter Linkages in Two Institutionalized Party Systems." PhD Diss., Uni-

Madrid, Raúl versity of North Carolina at Chapel Hill.

2003 Retiring the State. Stanford: Stanford University Press.

Mainwaring, Scott, and Timothy R. Scully

2003 "The Diversity of Christian Democracy in Latin America." In Christian Democracy in Latin America, edited by Scott Mainwaring and Timothy R. Scully, 30-63. Stanford: Stanford University Press.

Martínez Barahona, Elena

2001 "Uruguay." In Partidos políticos de América Latina, edited by Manuel Alcantara and Flavia Freidenberg, 425-557. Salamanca: University of Salamanca Press.

Midaglia, Carmen

2000 Alternativa de protección a la infancia carenciada. Buenos Aires: Consejo Latinoamericano de Ciencias Sociales.

Mideplan

2001 "Focalización e impacto distributivo de los subsidios monetarios." Documento de trabajo \#3. Santiago: Government of Chile.

Mizala, Alejandra, with Pilar Romanguera, and Paulo Henriquez

n.d. "Female Labor Supply in Chile." University of Chile, Working Paper, Center for Applied Economics. http://ideas.repec.org/p/edj/ceauch/58.html.

Montecinos, Verónica

1998 Economists, Politics and the State: Chile 1958-1994. Amsterdam: CEDLA.

Murrugarra, Edmundo

2000 "Social Protection in Uruguay." World Bank Social Risk Management Background Readings. http://www.worldbank.org/wbi/socialprotection/Africa/ readings.html.

O'Connor, Julia S., Ann Shola Orloff, and Sheila Shaver

1999 States, Markets, Families. New York: Cambridge University Press.

Orloff, Ann Shola

1993 "Gender and the Social Rights of Citizenship: The Comparative Analysis of Gender Relations and Welfare States." American Sociological Review 58 (June): 303-328.

Portes, Alejandro, and Richard Schauffler

1993 "The Informal Economy in Latin America: Definition, Measurement, and Policies." In Work Without Protections: Case Studies of the Informal Sector in Developing Countries, edited by Gregory K. Schoepfle and Jorge F. Perez-Lopez, chap. 1. Washington D.C.: U.S. Department of Labor.

Uruguay, Presidencia de la República

2004 Extensión de la prestación del beneficio de asignación familiar. ley n ${ }^{\circ}$ 17.758. http://www.presidencia.gub.uy/ley/2004050401.htm (accessed January 1, 2006).

Ríos Tobar, Marcela

2004 "Feminism and the Transition to Democracy in Chile." In Promises of Empowerment, edited by Peter H. Smith, Jennifer L. Troutner, and Christine Hünefeldt, 103-124. Oxford: Rowman and Littlefield Publishers.

Sainsbury, Diane

1996 Gender, Equality, and Welfare States. New York: Cambridge University Press.

Schild, Verónica

2002 "Engendering the New Social Citizenship in Chile: NGOs and Social Provisioning under Neo-liberalism" in Gender Justice, Development, and Rights, edited by Maxine Molyneux and Shahra Razavi, 170-203. New York: Oxford University Press.

Servicio Nacional de la Mujer (Sernam)

n.d. "Base de Datos." http://www.sernam.gob.cl/basemujer (accessed February 2003).

United Nations Development Program (UNDP)

2004 "Human Development Report." http://hdr.undp.org/reports/global/2004/ 
U.S. Social Security Administration

1999 Social Security Programs Throughout the World. Washington D.C.: U.S. Government.

Van Kerbergen, Kees

1995 Social Capitalism. New York: Routledge Press. 